\title{
Evaluation of Physico-chemical Properties and Microbiological Quality of Milk Collected from Different Dairy Farms in Sylhet, Bangladesh
}

\author{
Abdul Kader, Mitu Deb, Md. Abdul Aziz", Md. Mehadi Hasan Sohag, Syeda Rumana Rahman \\ Department of Genetic Engineering and Biotechnology, Shahjalal University of Science and Technology, Bangladesh
}

Copyright $(\mathcal{C} 2015$ by authors, all rights reserved. Authors agree that this article remains permanently open access under the terms of the Creative Commons Attribution License 4.0 International License

\begin{abstract}
This study deals with the inspection of physical, chemical and microbiological quality of liquid cow's milk collected from four different dairy farms in Sylhet, Bangladesh. Several milk compositions were examined and assessed to the Bangladesh Standards (BDS) and Food and Agriculture Organization (FAO). Results showed that tastes of all milk samples were slightly sweet and the mean specific gravity $(1.029 \pm 0.0025$ to $1.032 \pm 0.0015)$ was within standard range. The color of milk of sample 1 displayed similarity to sample 3, and likewise sample 2 to sample 4 . However, all milk samples were normal except sample 2 which indicated cowy flavor and odor. The average statistics for fat $(3.40 \pm 0.26)$, protein $(3.47 \pm 0.11)$, total solids $(12.16 \pm 0.33)$, solid not fat $(8.76 \pm 0.32)$, acidity $(0.19 \pm 0.03)$ and $\mathrm{pH}$ $(6.67 \pm 0.10)$ were recorded. The Microbiological conclusion confirmed the presence of microbial population in all milk samples. The highest level of microbial quality in Standard Plate Count (SPC) was $38.1 \times 10^{6} \mathrm{cfu} / \mathrm{ml}$ in sample 3 and in logarithm the value is $7.58 \mathrm{cfu} / \mathrm{ml}$. Grades of milk were evaluated by Methyl Blue Reduction Test (MBRT) and this phenomenon testified that milk of sample 2 was fair in qualities than others. Statistical analysis revealed that there was no significant difference $(P>0.05)$ in the average values of acidity between results of milk samples to the BDS and FAO standards.
\end{abstract}

Keywords Raw Milk, MBRT Test, SPC Test, Chemical Properties, Bangladesh

\section{Introduction}

As an essential part of our daily diet, liquid milk plays a crucial role to meet up the increasing nutritional demand as well as ensures food safety in developing countries like Bangladesh. Containing several nutrients, milk includes a number of vital constituents like protein, carbohydrate, fat, vitamins and minerals [1] make it an absolute food to consume.

In Bangladesh a total of 4.78 million tonnes of milk is produced over the 2012-2013 fiscal year and about 90 percent of this production comes from cows while the rest is filled by buffaloes and goats. According to the DLS (Department of Livestock Services), the total requirement of milk consumption in our country is 1.46 crore tones per year. Among SAARC (South Asian Association for Regional Cooperation) countries, Bangladesh has the lowest milk consumption rate $(55 \mathrm{ml} /$ day $)$ and because of this scenario, BDT-750 crore has been spent to import powder milk annually [2].

Generally, liquid milk consumption is explicitly related to the quality of raw milk availed from different sources. The demand of milk is growing faster due to rapid increase in population. Therefore, the limited productions of milk lead the dairy personnel to adulterate milk with unhealthy liquor and other solid substances. The way of adulteration is occurred by unhygienic milking, inappropriate transport system, germ favored storage and milk collector itself which creates milk contaminated [3]. The safety of milk is of great concern in Bangladesh, specifically in Sylhet Metropolitan Area, where milk is collected and distributed by local milk suppliers to consumers through unsystematic way i.e., lack of proper filling (use of plastic buckets), storing (keeping milk long time in room temperature) and distributing procedures, using banana leaves for anti-agitation effect which can be a common source of contamination. Milk adulteration encourages the deterioration of the properties of raw milk [4] that apt to favorable condition for microbes to grow, particularly pathogenic bacteria [5] which are liable to cause various types of diseases.

A few works has been done on this aspect in Bangladesh but merely common in Sylhet Metropolitan Area. For this reason the present study was under taken with the aim of investigating the physico-chemical parameters as well as the microbiological quality of raw milk from different dairy 
farms in Sylhet, Bangladesh. This study was also compared to the Bangladesh standards (BDS) and Food and Agriculture Organization (FAO).

\section{Materials and Methods}

\subsection{Place of Study and Collection of Milk Samples}

The experiment was carried out at Animal Biotechnology Laboratory of Genetic Engineering and Biotechnology (GEB) in Shahjalal University of Science and Technology (SUST), Sylhet, Bangladesh. Here in, four different private farms of Amberkhana, Chatol, Kazirbazar and Zollarpar areas of Sylhet region were selected for sample collection (Table 1). Samples were collected in triplicate according to analytical procedures in investigation and the average value is indicated with standard deviation.

Table 1. Collection of Milk Samples

\begin{tabular}{|c|c|c|}
\hline S & Farm Name & Area of the Farm \\
\hline S 1 & Jahed Dairy Farm & Kazirbazar \\
\hline S 2 & Gram Bangla JouthoKhamar & Amberkhana \\
\hline S 3 & Younus Dairy Farm & Zollarpar \\
\hline S 4 & Chatol Integrated Farm & Chatol, Dolia \\
\hline
\end{tabular}

$* \mathrm{~S}=$ Sample

\subsection{Sampling}

At each farm, samples of approximately $500 \mathrm{ml}$ were taken aseptically from the bulk milk container into sterile plastic bottles. The milk was collected within 15 minutes of milking at ambient temperatures, kept on ice during approximately two hours of transportation and was analyzed immediately after arrival at the laboratory.

\subsection{Physico-chemical and Microbiological Analysis}

\subsubsection{Physical Analysis}

Sensory analysis was examined by a panel of twelve members. The organoleptic properties of milk such as color, flavor and odor, and taste were evaluated with the help of eyes, nose and tongue respectively as per standard score card [6]. Specific gravity was obtained by the use of lactometer and calculated [7].

\subsubsection{Chemical Analysis}

In this study, several chemical analyses has been done such as percentages (\%) of fat content, protein content, total solid (TS), solid not fat (SNF) and acidity. The analysis of fat content was determined by Gerber centrifuge method, total solid (TS) and acidity were considered according to the standard formula noted by [7]. Protein percentage of milk was carried out by formaldehyde method [8] and SNF of milk samples also calculated [9]. The CLR reading was followed by the instruction of standard methods for the determination of dairy products [10]. Another vital chemical property $\mathrm{pH}$ was measured by using $\mathrm{pH}$ meter.

\subsubsection{Microbiological Analysis}

Milk is highly perishable because it acts as an enrichment medium for growing and multiplication of the microbial community. The determination of microbial concentration is a crucial step for assuring public health. There are plenty of techniques available for detection of microorganisms. In present study, Methyl Blue Reduction Test (MBRT) and SPC (Standard Plate Count) were performed. MBRT was used because it is the most specified tool for the quick identification of microbial presence [11] where Methylene blue acts as an indicator. According to [12], the test is occurred into two stages that allow oxidation-reduction reaction. Here, oxygen is consumed by the bacterial population and then the dye became decolorized. Standard Plate Count was also observed in nutrient broth (LB) to determine the colony forming unit (cfu) [13].

\subsection{Data Analysis}

Data were presented as the mean \pm standard deviation (SD). The significant differences between means of collected samples to the BDS and FAO standards were designed at $P<0.05$ using one-sample t-test in Statistical Package for the Social Sciences (SPSS).

\section{Results}

Milk samples were brought into the laboratory immediately after collection and then processed. Therefore, samples were ready to determine the physical, chemical and microbiological qualities.

\subsection{Physical Analysis}

In this study, four samples were taken with three replications that provided usual flavor and odor except sample 2 while tastes of all samples were remained the same. In case of color, sample 1 and 3 represented yellowish white when the rest were whitish. The specific gravity showed slight variation among four samples that varied from 1.026 to 1.034 with an average of 1.031 (Table 2). 
Table 2. Physical Properties of Raw Milk from Collected Samples

\begin{tabular}{|c|c|c|c|c|}
\hline Sample & Flavor and Odor & Color & Taste & Specific Gravity (Mean \pm SD) \\
\hline Sample 1 & Normal & Yellowish White & Slightly Sweet & $1.031 \pm 0.0017$ \\
\hline Sample 2 & Cowy & Whitish & Slightly Sweet & $1.032 \pm 0.0015$ \\
\hline Sample 3 & Normal & Yellowish White & Slightly Sweet & $1.030 \pm 0.0031$ \\
\hline Sample 4 & Normal & Whitish & Slightly Sweet & $1.029 \pm 0.0025$ \\
\hline
\end{tabular}

\subsection{Chemical Analysis}

Milk samples were also triplicated before subjected to different types of chemical analyses such as percentages of fat, protein, solid not fat and total solid content. Acidity and $\mathrm{pH}$ of the milk were also measured (Table 3 ). The average fat content was 3.40 while it ranges from 3.10 to 3.70. In addition, the average value of protein, TS, SNF, acidity and $\mathrm{pH}$ were observed as 3.47, 12.16, 8.76, 0.19 and 6.67 respectively which are compared to BDS [14] and FAO ideals [15-17] (Figure 1).

Table 3. Chemical Properties of Raw Milk from Collected Samples

\begin{tabular}{|c|c|c|c|c|c|}
\hline Compositions & Sample 1 & Sample 2 & Sample 3 & Sample 4 & Mean \pm SD \\
\hline Fat & 3.50 & 3.10 & 3.70 & 3.30 & $3.40 \pm 0.26$ \\
\hline Protein & 3.40 & 3.63 & 3.49 & 3.38 & $3.47 \pm 0.11$ \\
\hline Total Solids & 12.20 & 12.27 & 12.47 & 11.70 & $12.16 \pm 0.33$ \\
\hline SNF & 8.70 & 9.17 & 8.77 & 8.40 & $8.76 \pm 0.32$ \\
\hline Acidity & 0.161 & 0.23 & 0.19 & 0.159 & $0.19 \pm 0.03$ \\
\hline pH & 6.73 & 6.57 & 6.60 & 6.77 & $6.67 \pm 0.10$ \\
\hline
\end{tabular}

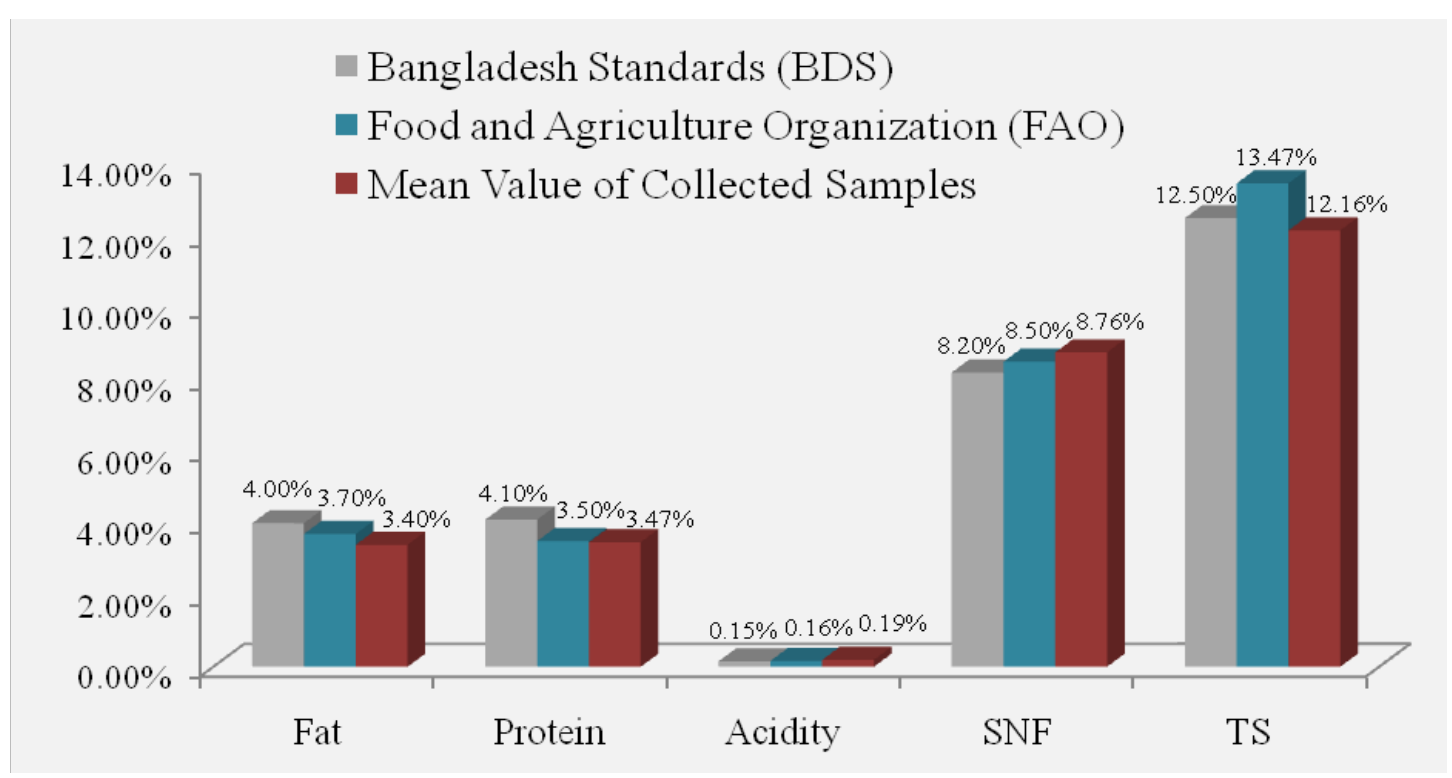

Figure 1. Comparison among the Mean Values of Milk Composition of Milk Samples, BDS and FAO data

\subsection{Microbiological Analysis}

Collected milk samples were further studied in test tubes and petridishes to spot microbial quality. MBRT was performed to evaluate the grading of milk quickly. Here the grades [18] of milk are confirmed within 6 hours duration in every 1 hour interval. Among all the samples, sample 2 indicated fair quality of milk when compared to sample 4 and the rest. Then Standard Plate Count was performed to observe the microbial load and measured in Colony Forming Unit (cfu). The cfu value for sample 1, 2, 3 and 4 were calculated as 7.45, 7.15, 7.58 and 7.37 respectively (Table 4). 
Table 4. SPC Count and MBRT of Collected Milk Samples

\begin{tabular}{|c|c|c|c|c|}
\hline Sample & $\begin{array}{c}\text { Standard Plate Count } \\
(\text { CFU/ml })\end{array}$ & $\begin{array}{c}\text { Standard Plate Count (log } \\
\text { CFU/ml })\end{array}$ & $\begin{array}{c}\text { Decolorization Time } \\
(\text { MBRT })\end{array}$ & Grade/Quality \\
\hline Sample 1 & $28.1 \times 10^{6}$ & 7.45 & Within 2 hours & Poor \\
\hline Sample 2 & $14.1 \times 10^{6}$ & 7.15 & From 3-4 hours & Fair \\
\hline Sample 3 & $38.1 \times 10^{6}$ & 7.58 & Within 2 hours & Poor \\
\hline Sample 4 & $23.4 \times 10^{6}$ & 7.37 & From 2-3 hours & Slightly Fair \\
\hline
\end{tabular}

\subsection{Statistical Analysis}

The statistics for the one-sample test is shown in the table 5. Results obtained from the statistical analysis evidenced that fat, protein and solid not fat were significant $(P<0.05, P<0.01$ and $P<0.05$ respectively) to BDS. Only the mean of total solids of the collected milk samples was statistically significant $(P<0.01)$ to FAO.

Table 5. One-sample Test for Chemical Properties of Milk Samples, BDS and FAO

\begin{tabular}{|c|c|c|c|c|c|c|c|c|}
\hline \multirow{2}{*}{ Compositions } & \multicolumn{2}{|c|}{ t-test statistic } & \multicolumn{2}{c|}{ Mean difference } & \multicolumn{2}{c|}{ Significant values (2-tailed) } & \multicolumn{2}{c|}{ Significance level } \\
\cline { 2 - 10 } & BDS & FAO & BDS & FAO & BDS & FAO & BDS & FAO \\
\hline Fat & -4.648 & -2.324 & -.6000 & -.3000 & .019 & .103 & $*$ & $\mathrm{n} / \mathrm{s}$ \\
\hline Protein & -10.977 & -0.439 & -.6250 & -.0250 & .002 & .690 & $* *$ & $\mathrm{n} / \mathrm{s}$ \\
\hline Total Solids & -2.078 & -8.005 & -.3400 & -1.310 & .129 & .004 & $\mathrm{n} / \mathrm{s}$ & $* *$ \\
\hline SNF & 3.534 & 1.641 & .5600 & .2600 & .039 & .199 & $*$ & $\mathrm{n} / \mathrm{s}$ \\
\hline Acidity & 2.110 & 1.507 & .0350 & .0250 & .125 & .229 & $\mathrm{n} / \mathrm{s}$ & $\mathrm{n} / \mathrm{s}$ \\
\hline
\end{tabular}

$* * *=P<0.001, * *=P<0.01, *=P<0.05$, (non-significant) $\mathrm{n} / \mathrm{s}=P>0.05$

\section{Discussion}

\subsection{Physical Analysis}

The study was performed with a view to evaluating the physical, chemical and microbial parameter of raw milk. First of all, the organoleptic properties showed the usual color, odor and taste with a minor deviation as color changes from yellowish white (sample 1 and 3 ) to whitish (sample 2 and 4) and in case of flavor, sample 2 was cowy flavor where the remaining samples were same. Among all samples, the highest value of specific gravity was recorded for sample 2 $(1.032 \pm 0.0015)$ and the lowest was sample $4(1.029 \pm 0.0025)$ (Table 2).

\subsection{Chemical Analysis}

In chemical analyses, the fat content was highest in sample 3 (3.70) and lowest in sample 2 (3.10). For sample 1 and 4 it was estimated as 3.50 and 3.30 respectively. Protein content was uppermost in sample 2 (3.63) and lowermost in sample 4 (3.38) when sample 1 and sample 3 showed a little drift. sample 4 showed nominal magnitudes for both TS (11.70) and SNF (8.40) as in that order, utmost of these were recorded in sample 3 (12.47) and sample 2 (9.17). The range of acidity was varied from 0.159 to 0.23 as $\mathrm{pH}$ between 6.57 and 6.77 (Table 3).

Afterward, the evaluated mean value of chemical compositions was contrasted with the BDS and FAO standards. The mean proportion for fat, protein and total solids of the milk samples were less than the usual value of BDS and FAO standards. In contrast, acidity and solid not fat were higher. The analyzation of the chemical properties of individual samples suggested that, in sample 4 the percentage of acidity $(0.159 \%)$ and solid not fat $(8.40 \%)$ were more or less similar to BDS (Acidity $=0.15 \%$ and SNF $=8.20 \%$ ) and FAO (Acidity $=0.16 \%$ and $\mathrm{SNF}=8.50 \%$ ) level whereas, protein in sample $2(3.63 \%)$ appeared more inferior than BDS $(4.10 \%)$ but little bit superior than FAO $(3.50 \%)$ standards (Figure 1).

\subsection{Microbiological Analysis}

The event of microbiological analysis showed that the highest standard plate count was in sample $3\left(38.1 \times 10^{6}\right)$. Minute standard plate count was confirmed in sample 2 $\left(14.1 \times 10^{6}\right)$. Standard plate count for sample $1\left(28.1 \times 10^{6}\right)$ and sample $4\left(23.4 \times 10^{6}\right)$ varied to some extent in between the values of sample 2 and sample 3 (Table 4).

MBRT of collected milk samples were carried out by observing decolorization time period. Sample 1 and 3 were decolorized within 2 hours but sample 4 took about 2-3 hours. Whereas, milk collected from sample 2 retained maximum time period (3-4 hours) to change its color from blue to white.

\subsection{Statistical Analysis}

It was observed that the comparison between the mean values of fat of milk samples and BDS standards was significant $(P<0.05)$. There was non-significant $(P>0.05)$ 
difference in fat content between milk samples and FAO standards. Amount of protein content in the samples was higher $(P>0.05)$ than that of FAO but the difference between collected samples and BDS was significant $(P<0.01)$. SNF in collected samples was also higher $(P>0.05)$ than that of the FAO standards. By comparing means of SNF content of collected milk samples and BDS, statistically significant correlation $(P<0.05)$ was obtained. However, the variability of TS in milk samples was related significantly $(P<0.01)$ with FAO and in contrast, the value was non-significantly $(P>0.05)$ different with BDS. On the other hand, the results showed no significance $(P>0.05)$ in mean values of acidity among the collected milk samples, BDS and FAO standards (Table 5).

\section{Conclusions}

The quality and composition of raw cow milk depends on its physico-chemical parameters that vary from one dairy farm to another. Moreover, the quality and compositions are affected by several factors such as type of breeds, forage consumption, feeding schemes, milking incidence, milking process, seasonal changes, lactation period and adulteration. On the other hand, high level of microbial loads brought about by unhygienic distributions of raw milk by the dairy farmers also reduces the standard of milk. The outcome of this study showed that, all the milk compositions were significantly correlated with the BDS and FAO recommended values except acidity which require more attention to ensure the quality of milk. These findings will evoke awareness in governmental companies as well as publics to be assembled to monitor the standard regulation of milk compositions in every dairy farm.

\section{Acknowledgements}

The Authors are thankful to the Department of Genetic Engineering and Biotechnology, Shahjalal University of Science and Technology, Sylhet for technical and financial support to carry out this study.

\section{REFERENCES}

[1] E. S. Komorowski, R. Early. Liquid milk and cream, In: The technology of dairy products, R. Early (Chief ed), VCH Publishers, Inc., New York, 22-24, 1992.

[2] BSS (Bangladesh Sangbad Sangstha). Country imports milk about Tk $750 \mathrm{cr}$ annually, 2013.

[3] F. Tasci. Microbiological and chemical properties of raw milk consumed in Burdur, Journal of Animal and Veterinary Advances, 10(5): 635-641, 2011.
[4] T. J. Hossain, K. Alam, D. Sikdar. Chemical and microbiological quality assessment of raw and processed liquid market milks of Bangladesh, Research Journal of Dairy Sciences, 4(4): 28-34, 2010.

[5] C. V. Chandrasekhar. Effect of refrigeration on the micropopulation of raw and pasteurised milk, International Journal of Dairy Technology, 4(4): 253-256, 1951.

[6] ISO. International Organization for Standardization, ISO/TC-34/SC.6, Recommendation of the meeting of the ISO of meat and meat products, The Netherlands, 10-18, 1995.

[7] A. C. Chaudhury. Practical Dairy Science and Laboratory Methods, Scientific Book Agency, Calcutta, p. 209, 1959.

[8] R. Steinegger. The aldehyde value of milk, European Food Research and Technology, 10(11): 659-671, 1905.

[9] C. H. Eckles, W. B. Combs, M. Harold. Milk and Milk Products, 4th Edition, McGraw-Hill Book Company, p. 454, 1951.

[10] H. M. Wehr, J. F. Frank. Standard Methods for the Examination of Dairy Products, 17th Edition, American Public Health Association, Washington DC, USA, p. 551, 2004.

[11] P. P. Aglawe, C. M. Wadatkar. Microbial examination of milk sample from Nagpur region with reference to coliform, Food Science and Technology Letters, 3(1): 24-26, 2012.

[12] H. R. Thornton, E. G. Hastings. Studies on oxidation-reduction in milk: The methylene blue reduction test, Journal of Dairy Science, 13(3): 221-245, 1930.

[13] APHA. Standard Methods for the Examination of Water and Waste Water, A. E. Eaton, L. S. Clesceri, A. E. Greenberg (Chief ed), American Public Health Association, Maryland, United Book Press Inc., 1960.

[14] M. B. Hossain, S. R. Dev. Physiochemical characteristics of various raw milk samples in a selected dairy plant of Bangladesh, International Journal of Engineering and Applied Sciences, 1(3): 91-96, 2013.

[15] R. P. Aneja. World survey of traditional milk products, India and neighbouring countries including the Himalayan region, Technology of traditional milk products in developing countries (FAO animal production and health paper) (No 85), Food and Agriculture Organization of the United Nations, Rome, Italy, 1989.

[16] FAO. Milk testing and quality control, FAO/TCP/KEN/6611 Project, Training Programme for Small Scale Dairy Sector and Dairy Training Institute, Naivasha, Kenya, Milk Processing Guide Series, Volume 2, 1998.

[17] P. Fellows, A. Hampton. Small-scale food processing: A guide to appropriate equipment, Intermediate Technology Publications, p. 158, 1992.

[18] H. V. Atherton, J. A. Newlander. Chemistry and Testing of Dairy Products, 4th Edition, AVI Publishing Co. Inc., Westport, CT., p. 396, 1977. 